\title{
Activation of HSD11B1 in the bovine cumulus-0ocyte complex during IVM and IVF
}

\author{
Masafumi Tetsuka and Misato Tanakadate \\ Department of Life and Food Science, Obihiro University of Agriculture and Veterinary Medicine, Obihiro, Hokkaido, Japan \\ Correspondence should be addressed to M Tetsuka: mtetsuka@obihiro.ac.jp
}

\begin{abstract}
The bovine cumulus-oocyte complex (COC) is capable of converting cortisone, an inert glucocorticoid to active cortisol. This mechanism is mediated by $11 \beta$-hydroxysteroid oxidoreductase type 1 (HSD11B1), whose expression dramatically increases in the mature COC. In this study, we investigate the time course expression of HSD11B1 and the enzyme activity in the bovine COC undergoing maturation and fertilization in relation to key events taking place in the COC. Bovine COCs were subjected to in vitro maturation (IVM) and fertilization (IVF). The activities of HSD11B1 and HSD11B2, which mediates the opposite reaction, were measured using a radiometric conversion assay. In parallel studies, cumulus expansion, P4 production and the expression of genes associated with ovulation were measured. The reductive activity of HSD11B1 increased in the latter half of IVM and remained high during IVF, whereas the oxidative activity of HSD11B2 remained unchanged over both periods. Consequently, the net glucocorticoid metabolism in the bovine COC shifted from inactivation to activation around the time of ovulation and fertilization. The increase in HSD11B1 expression lagged behind that of P4 increase and cumulus expansion but ahead of the expressions of genes responsible for PGE2 synthesis. The reductive activity of HSD11B1 was well correlated with the cumulus expansion rate. This outcome indicates that the ability of the cumulus to activate glucocorticoids is related to its ability to synthesize hyaluronan. These results also indicate that the activation of HSD11B1 is an integral part of the sequential events taking place at the ovulation and fertilization in the bovine COC.
\end{abstract}

Key Words
- HSD11B1
- cumulus-oocyte complex
- IVM
- IVF
- glucocorticoid

\section{Introduction}

The preovulatory LH surge triggers dynamic changes in the ovulatory follicle leading to a follicular rupture and subsequent luteinization. This ovulatory process takes some $24 \mathrm{~h}$ in cattle, during which the ovulating oocyte and surrounding cumulus oophorus also experience a series of morphological and biochemical changes (1). In the oocyte, both nuclear and cytoplasmic maturation progress, resulting in the appearance of a fertilizable and developmentally competent MII stage oocyte $(1,2,3)$. In the cumulus, the production and accumulation of hyaluronan and associated factors in the extracellular space results in cumulus expansion (4).
Gonadotropins also stimulate the production of progesterone (P4) and prostaglandin E2 (PGE2) in cumulus cells $(5,6,7,8)$. These hormones have been shown to play various roles in regulating the expression of many factors associated with oocyte maturation, fertilization and subsequent embryo development and cumulus expansion $(8,9,10,11,12)$.

Recently, we have demonstrated that the bovine oocyte cumulus complex (COC) undergoing IVM expresses two types of glucocorticoid metabolizing enzymes, namely 11ß-hydroxysteroid oxidoreductase type1 (HSD11B1) and type2 (HSD11B2) (13). The former is a reductase https://ec.bioscientifica.com https://doi.org/10.1530/EC-19-0188 (c) 2019 The authors Published by Bioscientifica Ltd
This work is licensed under a Creative Commons Attribution-NonCommercial-NoDerivatives 4.0 Internationab ticense.ifica.com at $04 / 26 / 2023 \quad 02: 52: 23 \mathrm{Am}$ 
that predominantly catalyzes inactive cortisone to active cortisol, while the latter is an oxidase that catalyzes the opposite reaction (14). The expression of these HSD11Bs appeared to be differentially regulated; cumulus cells only express HSD11B1, and its expression and activity increase in mature COCs, whereas oocytes only express HSD11B2, and its expression and activity remain unchanged irrespective of oocyte maturity (13). These results indicate that the local glucocorticoid environment in the bovine COC is eloquently regulated during oocyte maturation.

The physiological significance of the HSD11B-led glucocorticoid metabolism in the oocyte maturation has not yet been clarified. However, it is likely that the periovulatory activation of glucocorticoid is an integral part of complex events taking place in the bovine COC undergoing ovulation and fertilization. It is necessary to grasp the detailed expression pattern of HSD11B in relation to other factors involved in these events, to clarify its physiological role.

Therefore, in this study, we examined changes in the activity of HSD11B in the bovine cumulus-oocyte complex during maturation and subsequent fertilization and analyzed the expression pattern of HSD11B1 in relation to the expression of genes responsible for the production of P4 and PGE2, and for cumulus expansion.

\section{Materials and methods}

This study was approved by the Animal Experiment Committee of the Obihiro University of Agriculture and Veterinary Medicine (No. 28-127). All chemicals were supplied by Wako Pure Chemical Industries (Osaka, Japan) unless otherwise stated.

\section{The recovery of the cumulus-oocyte complex}

Bovine ovaries were harvested in a local slaughterhouse and brought to the laboratory in Dulbecco's phosphatebuffered saline (DPBS; Sigma-Aldrich). The cumulusoocyte complexes (COCs) were aspirated from follicles of 2-5 $\mathrm{mm}$ diameter using a syringe fitted with an 18-gauge needle. Only COCs with an evenly granulated cytoplasm and more than three layers of compact cumulus cells were used for the study.

\section{IVM and fertilization}

In vitro maturation (IVM) was conducted as mentioned elsewhere (13). Briefly, one or five COCs were cultured in either HLA Terasaki 60 multiwall plates (Greiner Bio One GmbH, Frickenhausen, Germany) or Nunc roundbottom 96 microwell plates (Thermo Fisher Scientific) containing $10-20 \mu \mathrm{L}$ or $100 \mu \mathrm{L}$ of HEPES modified medium 199 (Sigma-Aldrich) supplemented with 10\% (v/v) fetal calf serum (Fetal Clone III; Thermo Fisher Scientific), $100 \mu \mathrm{g} / \mathrm{mL}$ Kanamycine (Sigma-Aldrich), $100 \mu \mathrm{g} / \mathrm{mL}$ glutamine (Sigma-Aldrich), $1 \mu \mathrm{g} / \mathrm{mL}$ estradiol (Sigma-Aldrich) and $0.02 \mathrm{IU} / \mathrm{mL}$ FSH (Antrin R10; Kyoritsu Seiyaku, Tokyo, Japan) at $38.5^{\circ} \mathrm{C}$ for up to $24 \mathrm{~h}$ in $5 \% \mathrm{CO}_{2}$.

In vitro fertilization (IVF) was performed following the method reported by Hamano and Kuwayama (15). Briefly, frozen semen from a Holstein bull was thawed and washed twice by centrifugation for $5 \mathrm{~min}$ at $800 \boldsymbol{g}$ with sperm washing medium. The washed spermatozoa were subsequently suspended in modified Brackett and Oliphant's medium (16) supplemented with $1.25 \mathrm{U} / \mathrm{mL}$ heparin (Mochida Pharmaceuticals, Tokyo, Japan) and $5 \mathrm{mM}$ theophylline (Sigma-Aldrich) and adjusted to a final concentration of $3 \times 10^{6}$ cells $/ \mathrm{mL}$. Expanded COCs were washed in the IVF medium, transferred to wells of the HLA Terasaki 60 multiwall plate containing the IVF medium ( 1 oocyte $/ 20 \mu \mathrm{L}$ ) or round-bottom 96 microwell plate $(5$ oocytes $/ 50 \mu \mathrm{L})$ and incubated with or without spermatozoa for $5 \mathrm{~h}$ at $38.5^{\circ} \mathrm{C}$ in a humidified atmosphere of $2 \% \mathrm{CO}_{2}$ in air. Spermatozoa were also incubated alone to determine the activities of HSD11B.

\section{The measurement of HSD11B activities in COC}

The reductive and oxidative activities of HSD11B in COC were measured using the radiometric conversion assay reported previously (17). COCs were cultured as mentioned above with $100 \mathrm{pmol} / \mathrm{mL}$ of radiolabeled cortisol $\quad\left(\left[1,2,6,7-{ }^{3} \mathrm{H}(\mathrm{N})\right]\right.$-hydrocortisone $\quad 73.4 \mathrm{Ci} / \mathrm{mmol}$; PerkinElmer Japan) or cortisone $\left(\left[1,2-{ }^{3} \mathrm{H}\right]\right.$-cortisone $60 \mathrm{Ci} / \mathrm{mmol}$; American Radiolabeled Chemicals Inc., Tokyo, Japan). After culturing, the medium was recovered and the steroids were extracted once with $1 \mathrm{~mL}$ diethyl ether for $5 \mathrm{~min}$. The organic phase was removed and evaporated at $60^{\circ} \mathrm{C}$ under gentle stream of nitrogen until dry. The residue was dissolved in $10 \mu \mathrm{L}$ ethyl acetate containing $1 \mathrm{mM}$ each of cold cortisol and cortisone and subjected to thin layer chromatography (TLC) using a solvent system chloroform:ethanol, 92:8 (vol/vol) (17). After the TLC, the separated steroids were localized under UV $(254 \mathrm{~nm})$, and each area was cut out to determine the specific radioactivity. The activities of HSD11Bs were calculated from the percentage of counts detected as

This work is licensed under a Creative Commons Attribution-NonCommercial-NoDerivatives 4.0 Internationab ticense.ifica com at $04 / 26 / 2023 \quad 02: 52: 23 A M$ 
the product to total counts (substrate and product) after correction for the corresponding blank counts.

\section{Progesterone assay}

The concentration of progesterone (P4) in the culture medium was determined using a commercial kit (Progesterone EIA kit; Cayman Chemical Co.) following the protocol supplied by the company. The intra- and inter-assay coefficients of variation were less than $10 \%$.

\section{Cumulus size measurement}

COCs were individually cultured as mentioned above, and digital images of COCs were acquired before and after IVM. The size of the COCs was determined using ImageJ (National Institutes of Health). The cumulus expansion rate was calculated by dividing the size of the COC after IVM with the size before IVM.
RNA extraction, reverse transcription (RT) and real-time quantitative PCR

Total RNA was extracted from COCs using TRIzol Reagent (Life Technologies). The RT of extracted RNA and removal of any contaminating genomic DNA was performed with a QuantiTect Reverse Transcription kit (QIAGEN GmbH) following the procedure provided by the manufacturer. The abundance of mRNAs was quantified via real-time PCR using FastStart Essential DNA Green Master (Roche Diagnostics $\mathrm{GmbH}$ ) and Light Cycler Nano (Roche). Specific primers for target genes were designed using the National Centre for Biotechnological Information (NCBI) primer designing tool, Primer-BLAST (18) based on the reported bovine sequences (Table 1 ). The amplification program consisted of an initial activation at $95^{\circ} \mathrm{C}$ for 10 min followed by 45 cycles of the amplification steps: denaturation at $94^{\circ} \mathrm{C}$ for $10 \mathrm{~s}$, annealing at $60^{\circ} \mathrm{C}$ for $10 \mathrm{~s}$ and extension at $72^{\circ} \mathrm{C}$ for $15 \mathrm{~s}$. For quantifications of the target genes, standard curves were generated using

Table 1 Primers used for quantitative real-time PCR.

\begin{tabular}{|c|c|}
\hline Gene (bp) & Primer \\
\hline HSD11B1 & $\mathrm{F}$ \\
\hline (111) & $\mathrm{R}$ \\
\hline $\mathrm{H} 6 P D H$ & $\mathrm{~F}$ \\
\hline (62) & $\mathrm{R}$ \\
\hline STAR & $\mathrm{F}$ \\
\hline (149) & $\mathrm{R}$ \\
\hline CYP11A1 & $\mathrm{F}$ \\
\hline (118) & $\mathrm{R}$ \\
\hline HSD3B1 & $F$ \\
\hline (118) & $\mathrm{R}$ \\
\hline GFPT2 & $\mathrm{F}$ \\
\hline (134) & $\mathrm{R}$ \\
\hline HAS2 & $\mathrm{F}$ \\
\hline (142) & $\mathrm{R}$ \\
\hline PLA2G4A & $\mathrm{F}$ \\
\hline (136) & $\mathrm{R}$ \\
\hline PTGS2 & $\mathrm{F}$ \\
\hline (108) & $\mathrm{R}$ \\
\hline PTGES1 & $\mathrm{F}$ \\
\hline (111) & $\mathrm{R}$ \\
\hline$R P L 4$ & $\mathrm{~F}$ \\
\hline (116) & $\mathrm{R}$ \\
\hline RPL15 & $\mathrm{F}$ \\
\hline (90) & $\mathrm{R}$ \\
\hline TBP & $\mathrm{F}$ \\
\hline (200) & $\mathrm{R}$ \\
\hline
\end{tabular}

\begin{tabular}{l} 
Sequence $\left(5^{\prime}\right.$-3') \\
\hline AAGCAGACCAACGGGAGCATT \\
GGAGAAGACCCATCCAGAGCA \\
AGCCTGTGTGTGCCAGTTC \\
CCCAGGGTTIACTGCCAGCC \\
CAGCAGAAGGGTGTCATCAGAG \\
AGGACCTGGTTGATGATGGTCT \\
CCCTGAAAGTGACTTGGTTCTTCA \\
GTCAAACTTGTCCGGACTGGAG \\
CCTTGTACACTTGTGCCCTGAG \\
AACTTGCAGTGATTGGTCAGGA \\
CCGGACAAGGAAGGAGATTTTT \\
TTGACGAGCTGGATATGCCTTT \\
TTTCGGATGTGTCCAGTGC \\
TCGGTTCGTTAGATGCCTGT \\
CAAGGACCCAAAGGCACTGAAC \\
CGGCACGTCCTTCTCTGGTATT \\
TCTACCCGCCTCATGTTCCT \\
TGTGTTCCCGTAGCCAAATG \\
CCGATGGCCCTTTGAGATTG \\
CAAGGGACACACGGGGAAAC \\
ACTCCGAGCACCACGCAAGA \\
TGGTGTTCCTGCGCATGGTCT \\
GCGGCAGCCATCAGGGTGAG \\
AGGAAGCGCATCACGTCCGA \\
GCCTTGTGCTTACCCACCAACAGTTC \\
TGTCTTCCTGAAACCCTTCAGAATAGGG \\
\hline
\end{tabular}

\begin{tabular}{lcc}
\hline GenBank no. & & Position $^{\mathbf{a}}$ \\
\cline { 1 - 2 } NM001123032.1 & $532-552$ \\
BC120346.1 & $642-621$ \\
NM174189.3 & $766-785$ \\
NM176644.2 & $916-897$ \\
& $767-788$ \\
NM174343.3 & $915-894$ \\
& $1209-1232$ \\
NM001076883.1 & $1326-1305$ \\
& $640-661$ \\
NM174079.3 & $757-736$ \\
NM001075864.1 & $95-116$ \\
& $229-208$ \\
NM174445.2 & $1362-1380$ \\
NM174443.2 & $1503-1484$ \\
& $1464-1485$ \\
NM001014894.1 & $1599-1578$ \\
NM001077866.1 & $888-907$ \\
NM001075742.1 & $995-976$ \\
& $538-557$ \\
& $648-629$ \\
& $945-964$ \\
& $1060-1040$ \\
& $17-36$ \\
& $106-87$ \\
& $133-1158$ \\
& $1332-1305$ \\
\hline
\end{tabular}

a Nucleotide position in the reported sequence.

CYP11A1, cytochrome P450, family 11, subfamily A, polypeptide 1; GFPT2, glutamine-fructose-6-phosphate transaminase 2; H6PDH, hexose-6-phosphate dehydrogenase; HAS2, hyaluronan synthase 2; HSD11B1, 11ß-hydroxysteroid oxidoreductase type 1; HSD3B, hydroxy-delta-5-steroid dehydrogenase, 3 beta- and steroid delta-isomerase 1; PLA2G4A, phospholipase A2 group IVA; PTGES1, prostaglandin E2 microsomal synthase 1; PTGS2, prostaglandinendoperoxide synthase 2; $R P L 15$, ribosomal protein $L 15 ; R P L 4$, ribosomal protein $L 4 ; S T A R$, steroidogenic acute regulatory protein; TBP, TATA-box-binding protein.

https://ec.bioscientifica.com https://doi.org/10.1530/EC-19-0188 (c) 2019 The authors Published by Bioscientifica Ltd

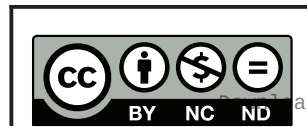

This work is licensed under a Creative Commons Attribution-NonCommercial-NoDerivatives 4.0 Internationab sicense.ifica . com at $04 / 26 / 2023 \quad 02: 52: 23 \mathrm{AM}$ 
sets of serially diluted cDNA samples. The results were normalized to geometric means of three stably expressed reference genes, ribosomal protein L4 (RPL4), ribosomal protein L15 (RPL15), and TATA-binding protein (TBP), following the procedure reported by Vandesompele et al. (19). The intra- and inter-assay coefficients of variation were less than 15\% for all measurements.

\section{Statistical analysis}

All statistical analyses were performed using the computing environment R (20) installed with R Commander and Easy $\mathrm{R}$ (21). Data were transformed to base-10 logarithms when not normally distributed. Comparisons between two data samples were performed using an unpaired two-tailed t-test. Comparisons among multiple data samples were performed using either Tukey's multiple comparison test (comparisons between two consecutive time points: for example, P4 levels and COC size) or Dunnett's multiple comparison test (comparisons between gene expressions at $\mathrm{Oh}$ and at each of the following time point). The effects of HSD11B isozymes and the presence of spermatozoa on the enzyme activities were analyzed using a two-way ANOVA, and differences among the groups were analyzed using Tukey's test. Data were presented as an arithmetic mean \pm s.E.M. The correlation between HSD11B activities and the size of COC or the degree of cumulus expansion, and the correlation between HSD11B1 activities during IVM and IVF periods were analyzed using Pearson's correlation coefficient. Differences between groups were considered statistically significant when the $P$ value was less than 0.05 .

\section{Results}

\section{The effect of spermatozoa on the activities of HSD11B in the bovine cumulus-oocyte complex}

Bovine COCs were subjected to IVM (5 COCs/100 $\mu \mathrm{L} /$ well) for $21 \mathrm{~h}$ and then incubated with (IVF+) or without (IVF-) spermatozoa for $5 \mathrm{~h}$ in the $\mathrm{BO}$ medium (5 COCs $/ 50 \mu \mathrm{L} /$ well) containing labeled cortisone or cortisol to determine the reductive or oxidative activities of the HSD11B. Cumulus expansion was observed after $21 \mathrm{~h}$ of IVM. Five-hour incubation with spermatozoa dispersed the expanded cumulus (Fig. 1A). The reductive activity of HSD11B was twice as high as the oxidative activity both in the IVF+ and IVF- groups $(P<0.05)$. The HSD11B activities tended to decrease in the presence of spermatozoa $(P<0.1)$. No HSD11B activity was detected in the spermatozoa (Fig. 1B).

The activities of HSD11B reductase and oxidase in the bovine cumulus-oocyte complex during IVM and IVF

Bovine COCs were subjected to IVM (1 COC/20 $\mu \mathrm{l} /$ well) for $21 \mathrm{~h}$ with labeled cortisone or cortisol. After IVM, each COC was washed in PBS to remove carryover steroids and further incubated with (IVF+) or without (IVF-) spermatozoa for $5 \mathrm{~h}$ with the respectively labeled steroids (1 COC/20 $\mu \mathrm{L} /$ well). During IVM, the oxidative activity of HSD11B was nearly twice as high as the reductive activity (Fig. 2A, $P<0.01$ ). During IVF, the reductive activity was two to three times higher than the oxidative activity (Fig. 2B, P<0.05). The time unit activity of HSD11B reductase was 3-5 times higher during IVF compared to

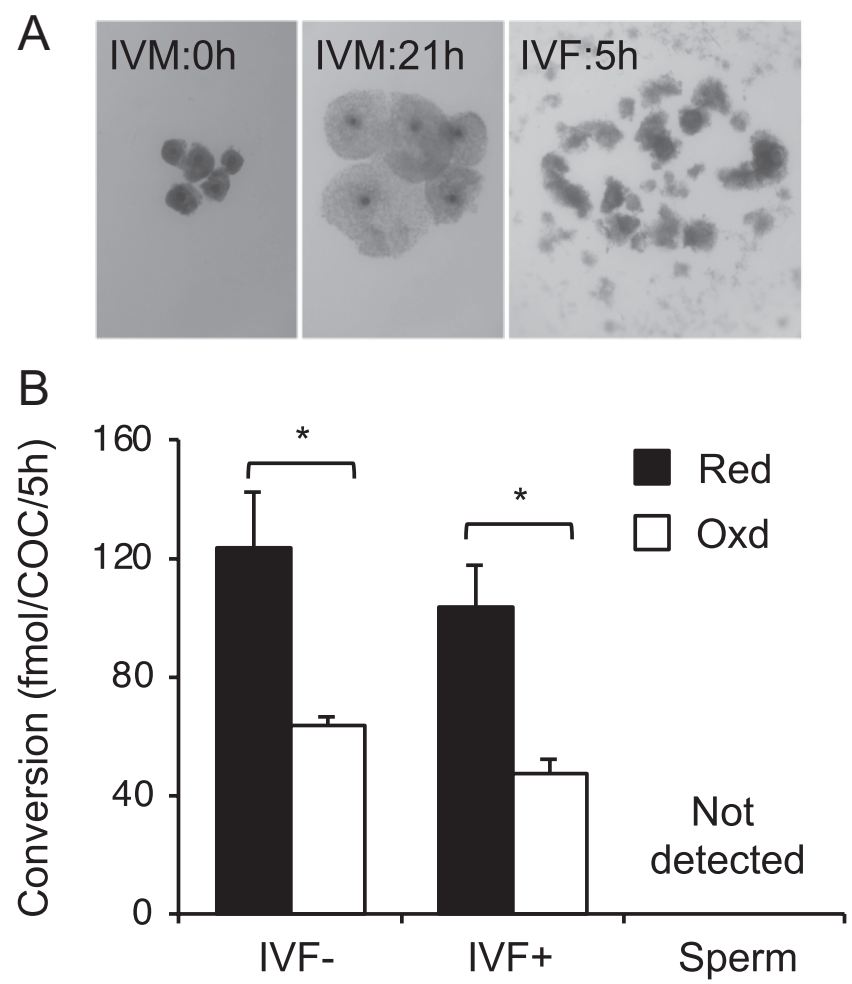

Figure 1

The reductive and oxidative activities of HSD11B in the bovine COC matured in vitro and cultured with and without spermatozoa. Bovine COCs (five COCs/well) were subjected to IVM for $21 \mathrm{~h}$ and then cultured in BO-containing radiolabeled cortisone/cortisol for $5 \mathrm{~h}$ with (IVF+) or without (IVF-) spermatozoa. (A) The morphology of COC before (IVM: $0 \mathrm{~h}$ ) and after (IVM: $21 \mathrm{~h}$ ) IVM, and after IVF (IVF: $5 \mathrm{~h}$ ). (B) The reductive (cortisone to cortisol; black bars) and the oxidative (cortisol to cortisone; open bars) activities of HSD11B in the COC and spermatozoa during the $5 \mathrm{~h}$ IVF period. Mean \pm S.E.M. $(n=4)$ 
A
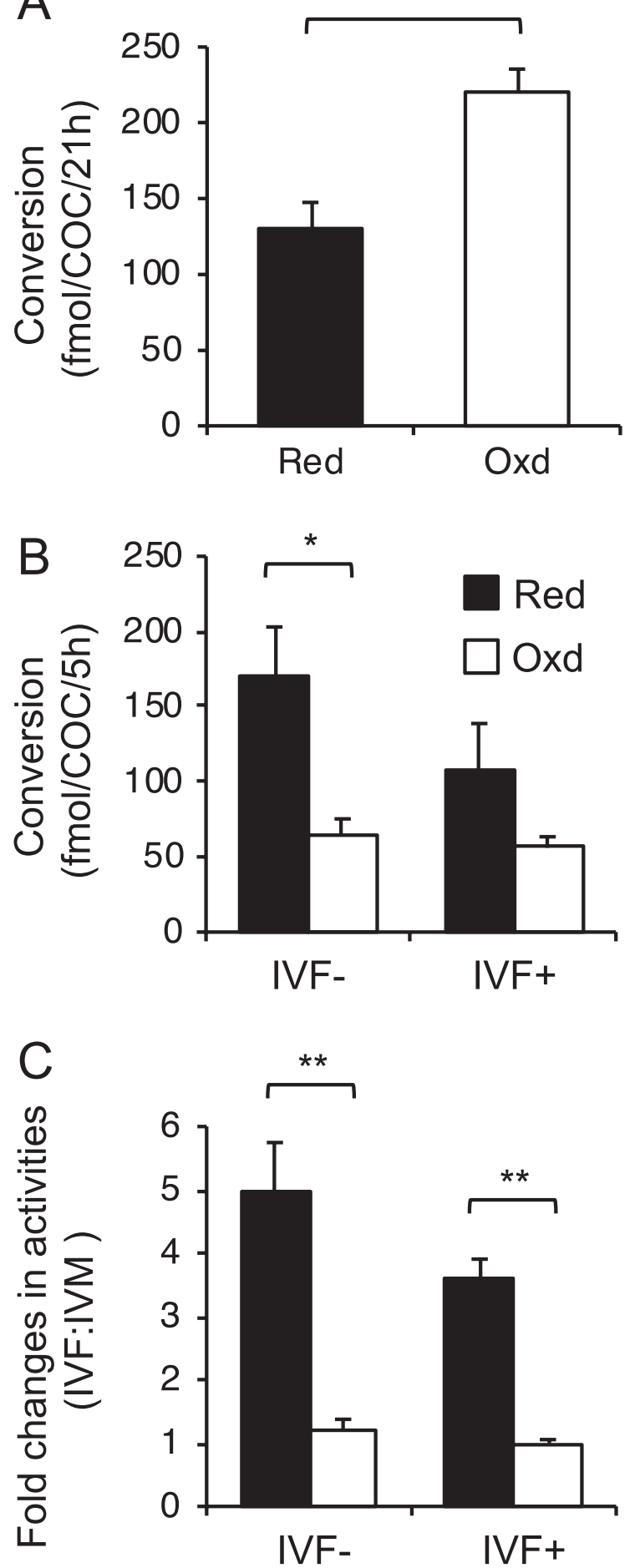

Figure 2

The reductive and oxidative activities of HSD11B in the bovine COC during the $21 \mathrm{~h}$ of IVM and following the 5-h culture with and without spermatozoa. The bovine COCs (1 COC/well) were subjected to IVM for $21 \mathrm{~h}$ and then cultured for $5 \mathrm{~h}$ with (IVF+) or without (IVF-) spermatozoa. The reductive (cortisone to cortisol; black bars) and the oxidative (cortisol to cortisone; open bars) activities of HSD11B were measured for IVM (A) and IVF (B) periods. The time-adjusted activities of HSD11B during IVM and IVF periods are also shown (C). Mean \pm S.E.M. (A: $n=16, \mathrm{~B}$ and C: $n=8)$.
IVM, while the activity of HSD11B oxidase was unchanged throughout IVM and IVF (Fig. 2C).

The relationships between cumulus size and HSD11B activities in the bovine cumulus-oocyte complex during IVM

There were significant correlations between the reductive activity of HSD11B over $21 \mathrm{~h}$ of the IVM period and the size of the cumulus at $21 \mathrm{~h}$, as well as the cumulus expansion rate (Table 2, $P<0.005$ ). No correlation was observed between the reductive activity and the size of cumulus at $0 \mathrm{~h}$. There was no correlation between the oxidase activity and cumulus size, nor the cumulus expansion rate (Table 2).

\section{Progesterone production, cumulus expansion and gene expression in the bovine cumulus-oocyte complex during IVM}

Bovine COCs ( $1 \mathrm{COC} / 10 \mu \mathrm{L} /$ well) were subjected to IVM for up to $24 \mathrm{~h}$ and COCs and spent medium were collected at $0,4,8,12,16,20$ and $24 \mathrm{~h}$ for the determination of gene expressions and $\mathrm{P} 4$ production. The size of the COCs and the expansion rate were calculated and recorded at $\mathrm{Oh}$ and each collection. The production of $\mathrm{P} 4$ was discernible at $4 \mathrm{~h}$ and accelerated between 8 and $16 \mathrm{~h}$, and then slowed down afterwards (Fig. 3A). Cumulus expansion was discernible at $8 \mathrm{~h}$ and the size of the cumulus steadily increased up to $20 \mathrm{~h}$ (Fig. 3B). Patterns of gene expression varied among genes (Fig. 4). The expression of HSD11B1 gradually and steadily increased during IVM (Fig. 4A). Similar patterns were observed for GFPT2, PLA2G4A and PTGS2 (Fig. 5F, $\mathrm{H}$ and I). The expressions of CYP11A1 and HAS2 increased over $4 \mathrm{~h}$ and then remained at high levels for the rest of the IVM period (Fig. 5D and G). The expression of $H 6 P D H$ and PTGES1 significantly decreased at 4 and $8 \mathrm{~h}$ and then increased toward the end of IVM (Fig. 5B and J), whereas HSD3B1 decreased at 8 and $12 \mathrm{~h}$ and then returned to the initial level afterward (Fig. 5E). The expression of STAR was largely unchanged throughout IVM except at $4 \mathrm{~h}$, where a relatively small but statistically significant increase was observed (Fig. 5C, p<0.05).

\section{Gene expression in the bovine cumulus-oocyte} complex matured in vitro and cultured with or without spermatozoa

Bovine COCs (5 COCs/100 $\mu \mathrm{L} /$ well) were subjected to IVM for $21 \mathrm{~h}$ then incubated with (IVF+) or without (IVF-) 
Table 2 Correlations between the size/expansion rate of the cumulus and the HSD11B activities in the bovine cumulusoocyte complex (COC) during IVM.

\begin{tabular}{|c|c|c|}
\hline \multirow[b]{2}{*}{ Variables } & \multicolumn{2}{|c|}{ Adjusted R-squared ( $P$ value) } \\
\hline & Reductive activity & Oxidative activity \\
\hline Cumulus size $0 \mathrm{~h}(\mathrm{~A})$ & $-0.067(P=0.805)$ & $-0.042(P=0.879)$ \\
\hline Cumulus size 21 h (B) & $0.766(P<0.001)$ & $-0.114(P=0.674)$ \\
\hline $\begin{array}{l}\text { Cumulus expansion } \\
\text { rate }(B / A)\end{array}$ & $0.729(P<0.005)$ & $-0.101(P=0.710)$ \\
\hline
\end{tabular}

spermatozoa for $5 \mathrm{~h}$ to determine the gene expression. Gene expression was significantly higher $(G F P T 2, P<0.05)$ or tended to be higher $(S T A R, P<0.1)$ in the IVF+ group compared to the IVF- group (Fig. 5).

\section{Discussion}

The results of this study demonstrated that the conversion of cortisone, an inert glucocorticoid, to active cortisol increases toward the end of IVM and stays high during IVF in the bovine COC. The opposite reaction also took place during IVM and IVF, but its activity was unchanged throughout these procedures. Consequently, the net metabolism of glucocorticoid in the bovine COC shifted from inactivation to activation around the expected time of ovulation and fertilization.

Two glucocorticoid-metabolizing enzymes, HSD11B1 and HSD11B2, are responsible for these conversions. HSD11B1 is a bi-directional 11HSD, which mainly acts as a reductase to convert cortisone to cortisol, whereas 11HSD2 acts as a dehydrogenase to catalyze the opposite reaction (14).

In the bovine $\mathrm{COC}$, the expressions of these HSD11Bs are well compartmentalized, and HSD11B1 is predominantly expressed in the cumulus cell. In contrast, HSD11B2 is only expressed in the oocyte (13).

The expression of HSD11B1 in the bovine COC was very low at the initiation of IVM. It began to increase at $4 \mathrm{~h}$, and then accelerated during the later half of the IVM. At IVM completion, the level of expression had increased by three orders of magnitude, making HSD11B1 the most acutely regulated gene among those examined. The gene expression of $\mathrm{H} 6 \mathrm{PDH}$, the enzyme responsible for generating the cofactor NADPH, which is necessary for HSD11B1 reductive activity (14), also increased during the later half of the IVM. Consequently, the reductive activity of HSD11B1 sharply increased toward the end of IVM and stayed high during IVF. In this study, a widespread disintegration of cumulus oophorus was apparent by $5 \mathrm{~h}$ after the introduction of spermatozoa. Bovine cumulus cells are rapidly lost from zygotes and early embryos after the fertilization (22). Although the expressions of HSD11B1 and H6PDH, as well as other genes associated with $\mathrm{P} 4$ and prostaglandin production, did not decrease, it is likely that the activity of these enzymes was rapidly lost as cumulus disintegration progressed (22).

This study demonstrates that bovine spermatozoa exert neither HSD11B1 nor HSD11B2 activity under the IVF conditions used. Various testes, epididymis and male accessory gland tissues express HSD11Bs and glucocorticoid receptors (GRs) in pigs (23) and rodents (24, $25,26)$. However, to our knowledge, neither the presence of HSD11Bs nor the functional GR in the spermatozoon has been demonstrated in any species.

Oviducts may convert glucocorticoids around the time of ovulation and fertilization. Bovine oviductal tissues collected at days 2-4 of the estrous cycle expressed HSD11B1 and HSD11B2 (27). However, expression levels were very low, and it is doubtful that there is any significant
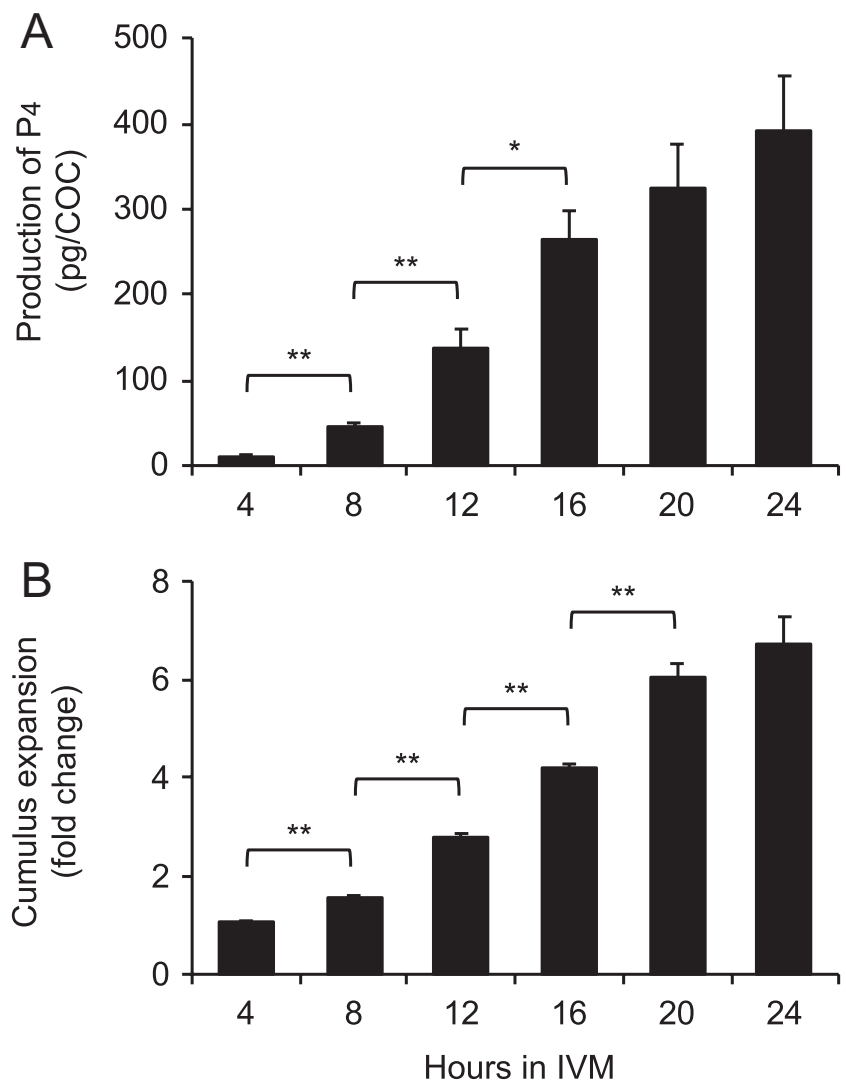

Figure 3

The progesterone production (A) and cumulus expansion (B) of the bovine COC during the 24-h IVM period. The bovine COCs (1 COC/well) were subjected to IVM for up to $24 \mathrm{~h}$, and the amount of P4 in the medium and size of the COC were measured at each time point. Mean \pm S.E.M. $(n=5)$.

This work is licensed under a Creative Commons Attribution-NonCommercial-NoDerivatives 4.0 Internationab bicense.ifica com at $04 / 26 / 2023 \quad 02: 52: 23 \mathrm{AM}$ 
A

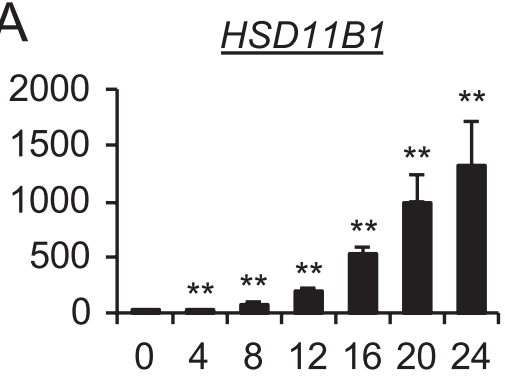

C

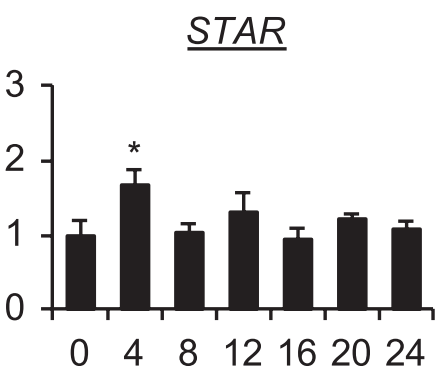

$E$
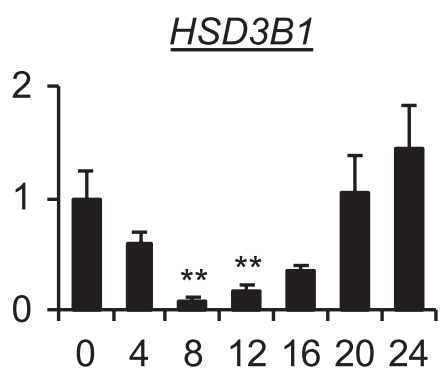

$G$
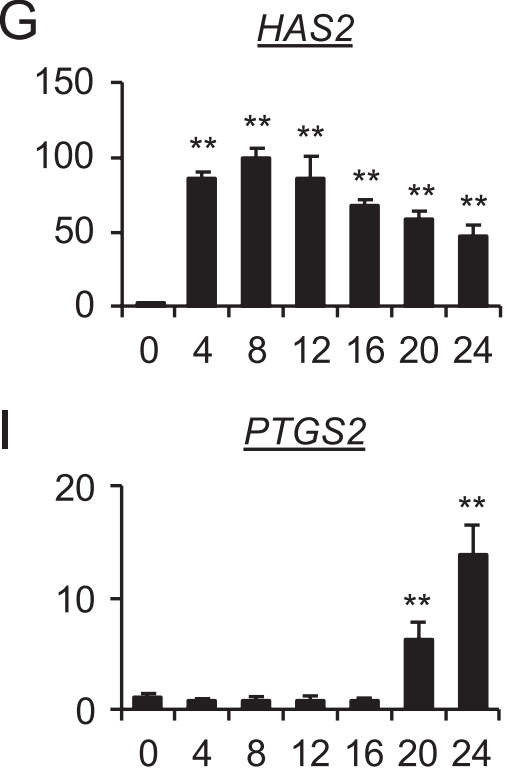

B

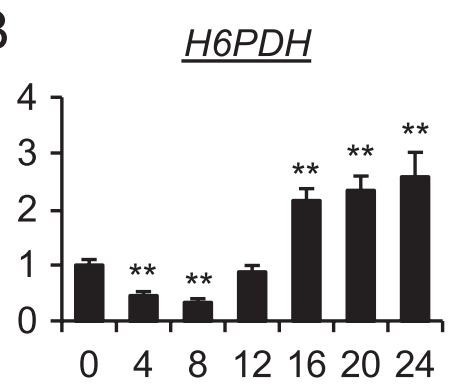

$\mathrm{D}$

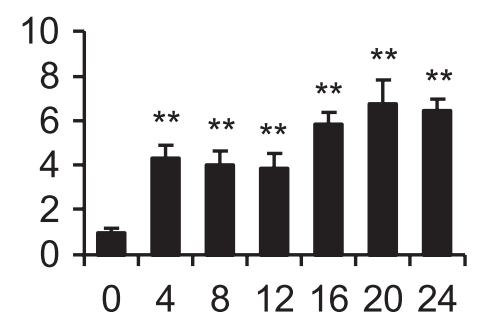

$\mathrm{F}$

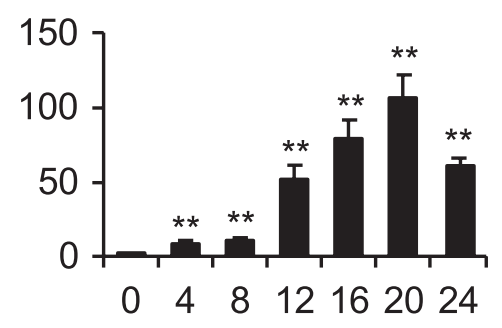

$\mathrm{H}$

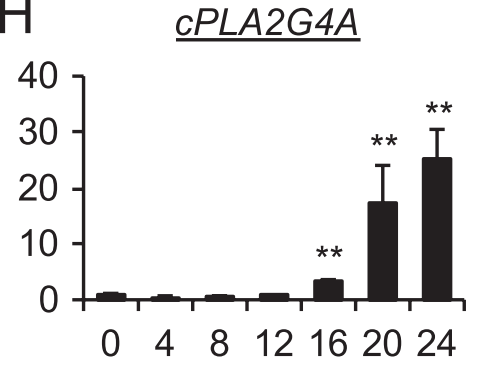

J

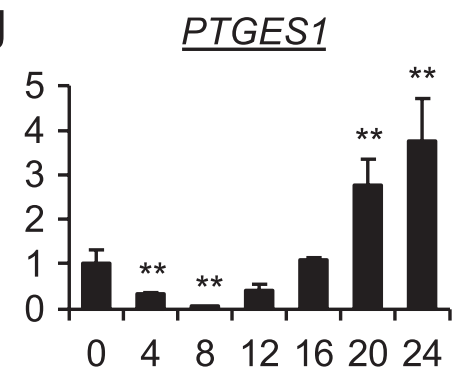

Hours in IVM

\section{Figure 4}

Changes in the expression of genes responsible for glucocorticoid activation (HSD11B1; A, H6PDH; $B)$, progesterone biosynthesis (STAR; C, CYP11A1; $D$, HSD3B1; E), cumulus expansion (GFPT2; F, HAS2; G) and PGE2 biosynthesis (PLA2G4A; $\mathrm{H}$, PTGS2; I, PTGES1; J) in the bovine COC during the 24-h IVM period. The levels of gene expression were normalized to the geometric means of three stably expressed reference genes: TBP, RPL4 and $R P L 15$. Mean \pm S.E.M. $(n=5)$. Significant differences from the expression levels at $0 \mathrm{~h} . * P<0.05$, $\star * P<0.01$. 
A

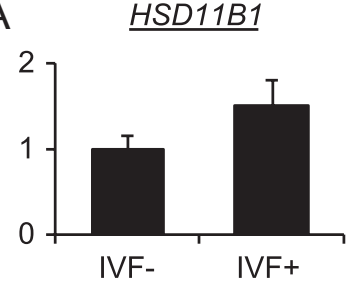

C

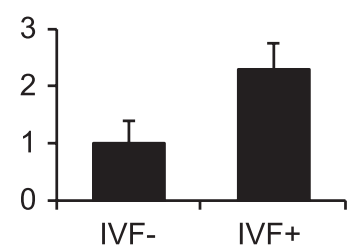

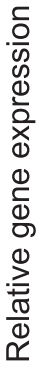

$E$

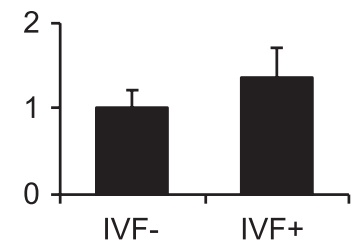

G

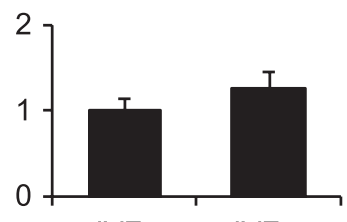

IVF-

IVF+

I

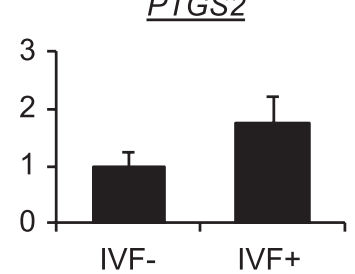

B $\quad \underline{H 6 P D H}$

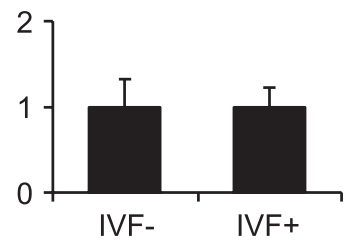

D

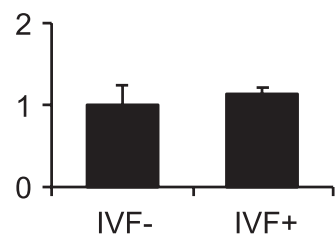

F

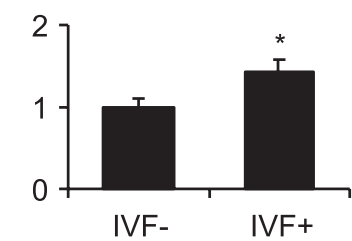

$\mathrm{H} \quad \underline{C P L A 2 G 4 A}$

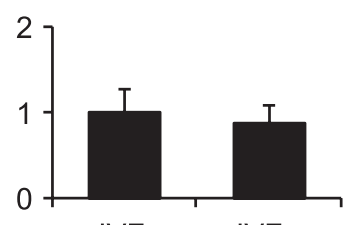

IVF- IVF+

\section{J}

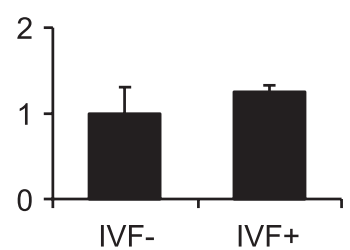

Treatment

\section{Figure 5}

The expression of genes responsible for glucocorticoid activation (HSD11B1: A, H6PDH: B), progesterone biosynthesis (STAR: C, CYP11A1: D, HSD3B1: E), cumulus expansion (GFPT2: F, HAS2: G) and PGE2 biosynthesis (PLA2G4A: H, PTGS2: I, PTGES1: J) in the bovine COC matured in vitro and incubated with and without spermatozoa for $5 \mathrm{~h}$. The gene expression levels were normalized to the geometric means of three stably expressed reference genes: TBP, RPL4 and RPL15. Mean \pm S.E.M. $(n=4)$. $\star P<0.05$.

HSD11B activity in the oviducts. In humans, it was shown that the oviduct exerts the oxidative activity of HSD11B2 but not the reductive activity of HSD11B1 (28).

These results indicate that bovine cumulus cells provide a temporal and local glucocorticoid umbrella around the oocyte at the time of ovulation and fertilization.

The HSD11B2 activity in the oocyte was fairly stable during IVM and IVF, despite ongoing dynamic events, such as nuclear and cytoplasmic maturation and fertilization. As there is little gene transcription taking place during oocyte maturation and fertilization, this is likely to be maintained by existing HSD11B2 or the newly translated enzyme from stored mRNA by post-transcriptional regulation (29). The HSD11B2-led inactivation of cortisol is likely to play an important role in protecting oocytes from the adverse effects of glucocorticoids during the maturation process. Pharmaceutical levels of glucocorticoids suppress oocyte maturation in mice $(30,31,32)$, sheep (33) and pigs (32, $34)$. However, in the presence of $18 \beta$-glycyrrhetinic acid (GA), a specific inhibitor of HSD11B2, lower levels of cortisol suppressed the oocyte maturation in mice and pigs (32). On the other hand, high levels of cortisol did not affect oocyte maturation in horses (35). These authors demonstrated that equine COC expresses HSD11B2, but not HSD11B1. These results may explain why equine COCs could withstand the negative effects of cortisol. Although the protective role of HSD11B2 in the bovine oocyte has not been clarified yet, the stable oxidative activity throughout maturation and fertilization implies that it is protected from circulating cortisol and locally generated cortisol during ovulation and fertilization.

The time course experiment in this study shows that the expression of enzymes involved in P4, PGE2, and hyaluronan production is differentially regulated during IVM. The expression of these enzymes is developmentally regulated in various species, including cattle $(6,7,36$, $37,38,39)$. The expression of CYP11A1 and HAS2, the rate-limiting enzymes for $\mathrm{P} 4$ and hyaluronan synthesis, respectively, increased to nearly maximum levels after $4 \mathrm{~h}$ of IVM. The production of $\mathrm{P} 4$ and the size of the cumulus also significantly increased after $4 \mathrm{~h}$, indicating that the functional enzymes were already at work. The expression of HSD11B1 lagged behind those of these enzymes. Although a slight but statistically significant increase in gene expression was observed at $4 \mathrm{~h}$, it is unlikely that a significant amount of cortisol was produced by this time. In a previous study, we were unable to detect any reductive activity of HSD11B1 in the bovine COC during the initial $5 \mathrm{~h}$ of IVM (13). The gene expressions of enzymes involved in PGE2 production, i.e., CPLA2G4A, PTGS2 and PTGES1, began to increase after 16-20 h of IVM, lagging HSD11B1 expression. These results are in accordance with those reported in bovine preovulatory follicles, where the expression of PTGS2 begins to increase $18 \mathrm{~h}$ after hCG treatment (40). However, this expression increases much later than in the results obtained for bovine COCs

This work is licensed under a Creative Commons Attribution-NonCommercial-NoDerivatives 4.0 elpternationab bicense.ifica.com at $04 / 26 / 2023 \quad 02: 52: 23 \mathrm{AM}$ 
subjected to IVM, where increases in expression begin after $6 \mathrm{~h}(5,6)$. This discrepancy in PTGS2 expression timings between this study and previous studies may be due to the difference in the number of COCs per culture. In the previous studies, up to 50 COCs were cultured in $500 \mu \mathrm{L}$ of medium, whereas in this study, COCs were cultured individually in $10 \mu \mathrm{L}$ of medium. Although the culture density is the same among these experiments, the presence of multiple COCs close to one another under static culture conditions may hasten the buildup of paracrine factors around the COCs and alter the pattern of gene expression.

The rise of $\mathrm{P} 4$ before an increase in HSD11B1 expression indicates the possible involvement of $\mathrm{P} 4$ in the periovulatory rise of HSD11B1 activity. P4 plays a pivotal role in the regulation of preovulatory follicular events, such as cumulus expansion and prostaglandin production (41). PGE2 may also affect HSD11B1 activity as well as the production of P4 during the later stages, as reported in cultured human granulosa-lutein cells (42, 43). Conversely, cortisol may regulate PGE2 production. Glucocorticoid suppresses ovarian PLA2 activity (44) and PGE2 production (45) in rats. Further study is required to elucidate these possibilities in the bovine COC.

In this study, a highly significant positive correlation between the reductive activity of HSD11B and the cumulus expansion rate was found. As there was no correlation between the enzyme activity and the size of the cumulus at the initiation of IVM, enzyme activity appears to be linked to the ability of the cumulus to expand, rather than the number of cells it contains.

In conclusion, the HSD11B1-led local production of cortisol increases toward the end of IVM and remains high during IVF in the bovine COC. This event occurs following the rise of $\mathrm{P} 4$ and the initiation of cumulus expansion and precedes the expression of genes involved in PGE2 synthesis. The results indicate that the activation of glucocorticoid is an integral part of the complex sequential events taking place in the bovine COC undergoing maturation and fertilization.

\section{Declaration of interest}

The authors declare that there is no conflict of interest that could be perceived as prejudicing the impartiality of the research reported.

\section{Funding}

This work was supported by Grant-in-Aid for Scientific Research (25450460 and 19K06365) to M T from the Japan Society for the Promotion of Science.

\section{Acknowledgements}

The authors are grateful to the staff of Genetics Hokkaido Association and Hokkaido Livestock Cooperation Doto Plant Tokachi Factory for providing bovine ovaries. They are also grateful to Dr Seizo Hamano of Tokyo BioTechnology Center, Livestock Improvement Association of Japan for crucial advises on IVM and IVF.

\section{References}

1 Hyttel P, Greve T \& Callesen H. Ultrastructural aspects of oocyte maturation and fertilization in cattle. Journal of Reproduction and Fertility: Supplement 198938 35-47.

2 Ferreira EM, Vireque AA, Adona PR, Meirelles FV, Ferriani RA \& Navarro PA. Cytoplasmic maturation of bovine oocytes: structural and biochemical modifications and acquisition of developmental competence. Theriogenology 200971 836-848. (https://doi. org/10.1016/j.theriogenology.2008.10.023)

3 Sirard MA, Florman HM, Leibfried-Rutledge ML, Barnes FL, Sims ML $\&$ First NL. Timing of nuclear progression and protein synthesis necessary for meiotic maturation of bovine oocytes. Biology of Reproduction 198940 1257-1263. (https://doi.org/10.1095/ biolreprod40.6.1257)

4 Russell DL \& Salustri A. Extracellular matrix of the cumulus-oocyte complex. Seminars in Reproductive Medicine 200624 217-227. (https:// doi.org/10.1055/s-2006-948551)

5 Calder MD, Caveney AN, Westhusin ME \& Watson AJ. Cyclooxygenase- 2 and prostaglandin $\mathrm{E}_{2}\left(\mathrm{PGE}_{2}\right)$ receptor messenger RNAs are affected by bovine oocyte maturation time and cumulusoocyte complex quality, and $\mathrm{PGE}_{2}$ induces moderate expansion of the bovine cumulus in vitro. Biology of Reproduction 200165 135-140. (https://doi.org/10.1095/biolreprod65.1.135)

6 Nuttinck F, Reinaud P, Tricoire H, Vigneron C, Peynot N, Mialot JP, Mermillod P \& Charpigny G. Cyclooxygenase-2 is expressed by cumulus cells during oocyte maturation in cattle. Molecular Reproduction and Development 200261 93-101. (https://doi. org/10.1002/mrd.1135)

7 Nuttinck F, Marquant-Le Guienne B, Clement L, Reinaud P, Charpigny G \& Grimard B. Expression of genes involved in prostaglandin $\mathrm{E}_{2}$ and progesterone production in bovine cumulusoocyte complexes during in vitro maturation and fertilization. Reproduction 2008135 593-603. (https://doi.org/10.1530/REP-070453)

8 Marei WF, Abayasekara DR, Wathes DC \& Fouladi-Nashta AA. Role of PTGS2-generated $\mathrm{PGE}_{2}$ during gonadotrophin-induced bovine oocyte maturation and cumulus cell expansion. Reproductive Biomedicine Online 201428 388-400. (https://doi.org/10.1016/j. rbmo.2013.11.005)

9 Aparicio IM, Garcia-Herreros M, O'Shea LC, Hensey C, Lonergan P \& Fair T. Expression, regulation, and function of progesterone receptors in bovine cumulus oocyte complexes during in vitro maturation. Biology of Reproduction 201184 910-921. (https://doi.org/10.1095/ biolreprod.110.087411)

10 Nuttinck F, Gall L, Ruffini S, Laffont L, Clement L, Reinaud P, Adenot P, Grimard B, Charpigny G \& Marquant-Le Guienne B. PTGS2-related PGE2 affects oocyte MAPK phosphorylation and meiosis progression in cattle: late effects on early embryonic development. Biology of Reproduction 201184 1248-1257. (https:// doi.org/10.1095/biolreprod.110.088211)

11 O'Shea LC, Hensey C \& Fair T. Progesterone regulation of AVEN protects bovine oocytes from apoptosis during meiotic maturation. Biology of Reproduction 201389 146. (https://doi.org/10.1095/ biolreprod.113.111880) https://ec.bioscientifica.com

https://doi.org/10.1530/EC-19-0188 (c) 2019 The authors Published by Bioscientifica Ltd
This work is licensed under a Creative Commons Attribution-NonCommercial-NoDerivatives 4.0 Internaționab ticense.ifica com at $04 / 26 / 2023 \quad 02: 52: 23 \mathrm{Am}$ 
12 Salehnia M \& Zavareh S. The effects of progesterone on oocyte maturation and embryo development. International Journal of Fertility and Sterility 20137 74-81.

13 Tetsuka M, Takagi R, Ambo N, Myat TS, Zempo Y \& Onuma A. Glucocorticoid metabolism in the bovine cumulus-oocyte complex matured in vitro. Reproduction 2016151 73-82. (https://doi. org/10.1530/REP-15-0363)

14 Chapman K, Holmes M \& Seckl J. 11 $\beta$-Hydroxysteroid dehydrogenases: intracellular gate-keepers of tissue glucocorticoid action. Physiological Reviews 201393 1139-1206. (https://doi. org/10.1152/physrev.00020.2012)

15 Hamano S \& Kuwayama M. In vitro fertilization and development of bovine oocytes recovered from the ovaries of individual donors: a comparison between the cutting and aspiration method. Theriogenology 199339 703-712. (https://doi.org/10.1016/0093691X(93)90255-4)

16 Brackett BG \& Oliphant G. Capacitation of rabbit spermatozoa in vitro. Biology of Reproduction 197512 260-274. (https://doi. org/10.1095/biolreprod12.2.260)

17 Thomas FJ, Thomas MJ, Tetsuka M, Mason JI \& Hillier SG. Corticosteroid metabolism in human granulosa-lutein cells. Clinical Endocrinology 199848 509-513. (https://doi.org/10.1046/j.13652265.1998.00457.x)

18 Ye J, Coulouris G, Zaretskaya I, Cutcutache I, Rozen S, Madden TL \& Primer B. A tool to design target-specific primers for polymerase chain reaction. Biomed Central Bioinformatics 201213 134. (https:// doi.org/10.1186/1471-2105-13-134)

19 Vandesompele J, De Preter K, Pattyn F, Poppe B, Van Roy N, De Paepe A \& Speleman F. Accurate normalization of real-time quantitative RT-PCR data by geometric averaging of multiple internal control genes. Genome Biology 20023 RESEARCH0034. (https://doi. org/10.1186/gb-2002-3-7-research0034)

20 R Development Core Team. R: a language and environment for statistical computing. Vienna, Austria: R Foundation for Statistical Computing, 2010. (available at: http://www.R-project.org)

21 Kanda Y. Investigation of the freely available easy-to-use software 'EZR' for medical statistics. Bone Marrow Transplantation 201348 452-458. (https://doi.org/10.1038/bmt.2012.244)

22 Familiari G, Verlengia C, Nottola SA, Tripodi A, Hyttel P, Macchiarelli G \& Motta PM. Ultrastructural features of bovine cumulus-corona cells surrounding oocytes, zygotes and early embryos. Reproduction, Fertility, and Development $199810315-326$. (https://doi.org/10.1071/R98004)

23 Sharp V, Thurston LM, Fowkes RC \& Michael AE. 11 $\beta$-Hydroxysteroid dehydrogenase enzymes in the testis and male reproductive tract of the boar (Sus scrofa domestica) indicate local roles for glucocorticoids in male reproductive physiology. Reproduction 2007134 473-482. (https://doi.org/10.1530/REP-07-0126)

24 Silva EJ, Queiroz DB, Honda L \& Avellar MC. Glucocorticoid receptor in the rat epididymis: expression, cellular distribution and regulation by steroid hormones. Molecular and Cellular Endocrinology 2010325 64-77. (https://doi.org/10.1016/j.mce.2010.05.013)

25 Gladstones GH, Burton PJ, Mark PJ, Waddell BJ \& Roberts P. Immunolocalization of $11 \beta$-HSD-1 and -2, glucocorticoid receptor, mineralocorticoid receptor and $\mathrm{Na}^{+} \mathrm{K}^{+}$-ATPase during the postnatal development of the rat epididymis. Journal of Anatomy $2012 \mathbf{2 2 0}$ 350-362. (https://doi.org/10.1111/j.1469-7580.2012.01481.x)

26 Hazra R, Upton D, Jimenez M, Desai R, Handelsman DJ \& Allan CM. In vivo actions of the Sertoli cell glucocorticoid receptor. Endocrinology 2014155 1120-1130. (https://doi.org/10.1210/ en.2013-1940)

27 Siemieniuch MJ, Majewska M, Takahashi M, Sakatani M, Lukasik K, Okuda K \& Skarzynski DJ. Are glucocorticoids auto- and/or paracrine factors in early bovine embryo development and implantation? Reproductive Biology 201010 249-256. (https://doi.org/10.1016/ S1642-431X(12)60045-X)
28 Muneyyirci-Delale O, Nacharaju VL, Kessel A, Yang L, Jalou S, Dalloul N, Rahman M, Bowers CH \& Abulafia O. Type 2 $11 \beta$-hydroxysteroid dehydrogenase activity in human fallopian tube and correlation of enzyme levels with endometrial histopathology. American Journal of Reproductive Immunology 200554 96-100. (https:// doi.org/10.1111/j.1600-0897.2005.00292.x)

29 Labrecque R \& Sirard MA. The study of mammalian oocyte competence by transcriptome analysis: progress and challenges. Molecular Human Reproduction 201420 103-116. (https://doi. org/10.1093/molehr/gat082)

30 Andersen CY. Effect of glucocorticoids on spontaneous and folliclestimulating hormone induced oocyte maturation in mouse oocytes during culture. Journal of Steroid Biochemistry and Molecular Biology 200385 423-427. (https://doi.org/10.1016/S0960-0760(03)00190-0)

31 Gonzalez R, Ruiz-Leon Y, Gomendio M \& Roldan ER. The effect of glucocorticoids on mouse oocyte in vitro maturation and subsequent fertilization and embryo development. Toxicology in Vitro $20102 \mathbf{2 4}$ 108-115. (https://doi.org/10.1016/j.tiv.2009.08.025)

32 Gong S, Sun GY, Zhang M, Yuan HJ, Zhu S, Jiao GZ, Luo MJ \& Tan JH. Mechanisms for the species difference between mouse and pig oocytes in their sensitivity to glucorticoidsdagger. Biology of Reproduction 201796 1019-1030. (https://doi.org/10.1093/biolre/ iox026)

33 Gonzalez R, Ruiz-Leon Y, Gomendio M \& Roldan ER. The effect of glucocorticoids on ERK-1/2 phosphorylation during maturation of lamb oocytes and their subsequent fertilization and cleavage ability in vitro. Reproductive Toxicology 201029 198-205. (https://doi. org/10.1016/j.reprotox.2009.10.009)

34 Yang JG, Chen WY \& Li PS. Effects of glucocorticoids on maturation of pig oocytes and their subsequent fertilizing capacity in vitro. Biology of Reproduction 199960 929-936. (https://doi.org/10.1095/ biolreprod60.4.929)

35 Scarlet D, Ille N, Ertl R, Alves BG, Gastal GDA, Paiva SO, Gastal MO, Gastal EL \& Aurich C. Glucocorticoid metabolism in equine follicles and oocytes. Domestic Animal Endocrinology 201759 11-22. (https:// doi.org/10.1016/j.domaniend.2016.10.004)

36 Schoenfelder M \& Einspanier R. Expression of hyaluronan synthases and corresponding hyaluronan receptors is differentially regulated during oocyte maturation in cattle. Biology of Reproduction 200369 269-277. (https://doi.org/10.1095/biolreprod.102.011577)

37 Schoenfelder M, Schams D \& Einspanier R. Steroidogenesis during in vitro maturation of bovine cumulus oocyte complexes and possible effects of tri-butyltin on granulosa cells. Journal of Steroid Biochemistry and Molecular Biology 200384 291-300. (https://doi.org/10.1016/ S0960-0760(03)00042-6)

38 Russell DL \& Robker RL. Molecular mechanisms of ovulation: co-ordination through the cumulus complex. Human Reproduction Update 200713 289-312. (https://doi.org/10.1093/humupd/ dml062)

39 Robker RL, Akison LK \& Russell DL. Control of oocyte release by progesterone receptor-regulated gene expression. Nuclear Receptor Signaling 20097 e012. (https://doi.org/10.1621/nrs.07012)

40 Sirois J. Induction of prostaglandin endoperoxide synthase- 2 by human chorionic gonadotropin in bovine preovulatory follicles in vivo. Endocrinology 1994135 841-848. (https://doi.org/10.1210/ endo.135.3.8070377)

41 Fair T \& Lonergan P. The role of progesterone in oocyte acquisition of developmental competence. Reproduction in Domestic Animals 201247 (Supplement 4) 142-147. (https://doi.org/10.1111/j.14390531.2012.02068.x)

42 Chandras C, Harris TE, Bernal AL, Abayasekara DR \& Michael AE. PTGER1 and PTGER2 receptors mediate regulation of progesterone synthesis and type $111 \beta$-hydroxysteroid dehydrogenase activity by prostaglandin $\mathrm{E}_{2}$ in human granulosa-lutein cells. Journal of Endocrinology 2007 194 595-602. (https://doi.org/10.1677/JOE-070128) 
43 Jonas KC, Chandras C, Abayasekara DR \& Michael AE. Role for prostaglandins in the regulation of type $111 \beta$-hydroxysteroid dehydrogenase in human granulosa-lutein cells. Endocrinology 2006 147 5865-5872. (https://doi.org/10.1210/en.2006-0723)

$44 \mathrm{Kol} \mathrm{S}$, Ben-Shlomo I, Payne DW, Ando M, Rohan RM \& Adashi EY. Glucocorticoids suppress basal (but not interleukin-1-supported) ovarian phospholipase A2 activity: evidence for glucocorticoid receptor-mediated regulation. Molecular and Cellular Endocrinology 1998137 117-125. (https://doi.org/10.1016/S0303-7207(98)00003-3)

45 Mikuni M, Mitsube K, Peterson CM \& Brannstrom M. Glucocorticoid suppression of intraovarian levels of prostaglandins and plasminogen activator activity at ovulation in the rat ovary. Journal of Obstetrics and Gynaecology Research 200935 1005-1011. (https://doi. org/10.1111/j.1447-0756.2009.01081.x)

Received in final form 5 June 2019

Accepted 26 June 2019

Accepted Preprint published online 26 June 2019
This work is licensed under a Creative Commons Attribution-NonCommercial-NoDerivatives 4.0 Internationab ticense.ifica.com at $04 / 26 / 2023 \quad 02: 52: 23 \mathrm{AM}$ 